\title{
Leveraging the potential of nature to meet net zero greenhouse gas emissions in Washington State
}

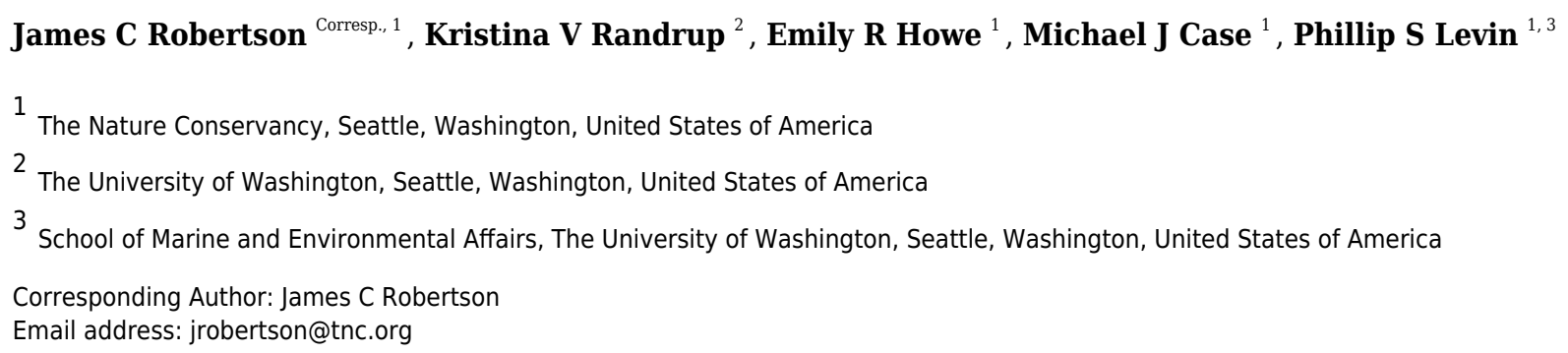

The State of Washington, USA, has set a goal to reach net zero greenhouse gas emissions by 2050 , the year around which the Intergovernmental Panel on Climate Change (IPCC) recommended we must limit global warming to $1.5{ }^{\circ} \mathrm{C}$ above that of pre-industrial times or face catastrophic changes. We employed existing approaches to calculate the potential for a suite of Natural Climate Solution (NCS) pathways to reduce Washington's net emissions under three implementation scenarios: Limited, Moderate, and Ambitious. We found that NCS could reduce emissions between 4.3 and 8.8 MMT $\mathrm{CO}_{2} \mathrm{e}^{\mathrm{yr}-1}$ in thirty-one years, accounting for $4 \%$ to $9 \%$ of the State's net zero goal. These potential reductions largely rely on changing forest management practices on portions of private and public timber lands. We also mapped the distribution of each pathway's Ambitious potential emissions reductions by county, revealing spatial clustering of high potential reductions in three regions closely tied to major business sectors: private industrial forestry in southwestern coastal forests, cropland agriculture in the Columbia Basin, and urban and rural development in the Puget Trough. Overall, potential emissions reductions are provided largely by a single pathway, Extended Timber Harvest Rotations, which mostly clusters in southwestern counties. However, mapping distribution of each of the other pathways reveals wider distribution of each pathway's unique geographic relevance to support fair, just, and efficient deployment. Although the relative potential for a single pathway to contribute to statewide emissions reductions may be small, they could provide co-benefits to people, communities, economies, and nature for adaptation and resiliency across the state. 


\title{
1 Leveraging the potential of nature to meet net zero
} 2 greenhouse gas emissions in Washington State

3

4

5

6

7

8

9

10

11

12

13

\author{
James C. Robertson ${ }^{1}$, Kristina V. Randrup ${ }^{2}$, Emily R. Howe ${ }^{1}$, Michael J. Case ${ }^{1}$, Phillip S. \\ Levin $^{1,3}$ \\ 1 The Nature Conservancy, Seattle, Washington, USA \\ 2 The University of Washington, Seattle, Washington, USA \\ 3 School of Marine and Environmental Affairs, The University of Washington, Seattle, Washington, USA
}

Corresponding Author:

James Robertson ${ }^{1}$

1517 North Oakes Street, Tacoma, Washington, 98406, USA

Email address: jrobertson@tnc.org

\section{Abstract}

The State of Washington, USA, has set a goal to reach net zero greenhouse gas emissions by 2050, the year around which the Intergovernmental Panel on Climate Change (IPCC) recommended we must limit global warming to $1.5^{\circ} \mathrm{C}$ above that of pre-industrial times or face catastrophic changes. We employed existing approaches to calculate the potential for a suite of Natural Climate Solution (NCS) pathways to reduce Washington's net emissions under three implementation scenarios: Limited, Moderate, and Ambitious. We found that NCS could reduce emissions between 4.3 and $8.8 \mathrm{MMT} \mathrm{CO}_{2} \mathrm{e}^{\mathrm{yr}-1}$ in thirty years, accounting for $4 \%$ to $9 \%$ of the State's net zero goal. These potential reductions largely rely on changing forest management practices on portions of private and public timber lands. We also mapped the distribution of each pathway's Ambitious potential emissions reductions by county, revealing spatial clustering of high potential reductions in three regions closely tied to major business sectors: private industrial forestry in southwestern coastal forests, cropland agriculture in the Columbia Basin, and urban and rural development in the Puget Trough. Overall, potential emissions reductions are provided largely by a single pathway, Extended Timber Harvest Rotations, which mostly clusters in southwestern counties. However, mapping distribution of each of the other pathways reveals wider distribution of each pathway's unique geographic relevance to support fair, just, and efficient deployment. Although the relative potential for a single pathway to contribute to statewide emissions reductions may be small, they could provide co-benefits to people, communities, economies, and nature for adaptation and resiliency across the state.

\section{Introduction}


40 The Intergovernmental Panel on Climate Change warned of significant impacts to economic, 41 ecological and social systems if average global temperatures exceed $1.5^{\circ} \mathrm{C}$ (IPCC, 2018). To prevent warming above this threshold, the world must reduce net emissions by $50 \%$ by 2030 and to zero by the middle of the century. Achieving this ambitious goal requires significant investment to reduce greenhouse gases emitted by the transportation, the built environment, and energy systems (Richter et al., 2008). Additionally, changes in land management, ecosystem restoration and conservation have the potential to increase carbon storage and avoid greenhouse gas (GHG) emissions across forests, wetlands, grasslands, and agricultural lands (Griscom et al., 2017). Such "Natural Climate Solutions" (NCS) can significantly contribute to $\mathrm{CO}_{2}$ equivalent $\left(\mathrm{CO}_{2} \mathrm{e}\right)$ emissions reduction goals at global (Griscom et al., 2017), national (Fargione et al., 2018), and regional levels (Cameron et al., 2017; Graves et al., 2020). Indeed, Griscom and colleagues (2017) suggested that if NCS were deployed in 2017, by 2030 they could mitigate over one-third of the GHG emissions needed to keep global warming below $2{ }^{\circ} \mathrm{C}$.

The reduction of GHGs is a global problem, and associated goals are often promulgated at international or national scales (Gupta, 2010). Implementation of NCS is fundamentally a natural resource matter, and thus in the United States is managed by landowners and legal authorities acting within nested and overlapping federal, state, and county regulatory and jurisdictional frameworks. While national and international agreements are necessary to create accountability and to deploy broadscale decisions, top-down approaches can impede effective solutions when they do not consider equity across land-use sectors in cross-scale decision-making (Landauer, Juhola \& Klein, 2019), consider indigenous and local community values (Scoones, 2016; Nightingale et al., 2019), or consider ecosystem-specific limitations (Bustamante et al., 2014). Thus, investigations of NCS must not only estimate the potential magnitude of emission reductions by various NCS approaches, but they must also reveal where on the landscape NCS opportunities exist. Understanding the geographic pattern of NCS opportunities is foundational to the equitable distribution of costs and benefits, the assessment of the social and political feasibility of different NCS strategies, and the assessment of social-ecological co-benefits of NCS implementation (Bustamante et al., 2014; Klinsky et al., 2017; Soto-Navarro et al., 2020).

In 2020, the Washington State (USA) legislature passed the Climate Pollutants Limits bill, which requires the state to reduce GHG emissions to $45 \%$ below 1990 levels by $2030,70 \%$ below 1990 levels by 2040, and 95\% below 1990 levels by 2050, plus offsets to address the final 5\% to achieve carbon neutrality (Washington State Legislature, 2020). This is the first law in the U.S. that sets a net zero target and keeps Washington in line with the goals of the Paris Climate Accord agreement. Importantly, this law explicitly establishes a policy to promote the removal of carbon from the atmosphere through voluntary and incentive-based sequestration activities on natural and working lands. That is, the bill specifically calls for the development of NCS as part of the State's net emissions reduction portfolio.

In this paper we aim to assess the degree to which NCS can contribute to Washington State's decarbonization policy. Moreover, because the geographic distribution of NCS opportunities in Washington State has not been systematically evaluated, we identify where on the landscape NCS pathways could be implemented to maximize carbon sequestration and prospective cobenefits.

As a first step in connecting specific NCS pathways to their appropriate geographies, and thereby to ecological and socio-economic systems, we quantified potential NCS emissions reductions in Washington State at the scale of counties. We report the potential magnitude and geographic 
85

86

87

88

89

90

91

92

93

94

95

96

97

98

99

100

101

102

103

104

105

106

107

108

109

110

111

112

113

114

115

116

117

118

119

120

121

122

123

124

125

126

distribution of carbon reductions of a series of NCS pathways at multiple spatial scales and levels of intensity. Our goal is to provide the foundational spatial information needed to conduct inclusive planning and assessments for climate mitigation and adaptation.

\section{Materials \& Methods}

\section{Study Context}

The latest account of Washington statewide emissions was 99.57 MMT $\mathrm{CO}_{2} \mathrm{e}$ in 2018 (WECY, 2021). To achieve a net zero goal by 2050 , reductions in emissions will have to occur directly within transportation, energy, agriculture, and industry, and the State also recognizes that increasing carbon sequestration rates and avoiding activities that continue GHG emissions in nature-based activities will be required (WECY, 2019; WA Governor's Office, 2019).

In this paper, we draw on existing methods (Griscom et al., 2017; Cameron et al., 2017; Fargione et al., 2018; Graves et al., 2020) to calculate emissions reductions potential from Natural Climate Solutions in Washington and for each of the 39 counties within the state.

We chose to focus on the county scale because Washington counties are feasible units for analyzing industry clusters, or regionally concentrated groups of closely related industries that may fall in different business sectors but are closely linked by local commerce between them (Chrisinger, Fowler \& Kleit, 2015). Regionalized climate solutions, including NCS, could be deployed within industry clusters to account for indirect and induced economic impacts as well as to create resilience for businesses involved. For example, the Washington maritime industry is implementing programs such as low emissions fleets and technical training to retain jobs in local communities (Washington State Department of Commerce, 2019). Moreover, county-level assessment is commonly used for social and resource-related objectives such as logistical deployment of state and federal programs like crop loss and disaster insurance (USDA NASS, 2020), annual timber harvest accounting (WDNR, 2018), state economic forecasts (Washington State Office of Financial Management, 2019), and equitable distribution of social programs and healthcare (Washington State Department of Health, 2018). County analysis units also allow finer-scaled socio-demographic analysis with US Census Tracts, Block Groups, and Blocks nested within their boundaries (U.S. Census Bureau, 2010).

\section{General Approach}

We calculated the emissions reduction potential of 11 NCS pathways (here referred to as pathways) in Washington State, USA, largely following the approaches used previously in the states of Oregon (Graves et al., 2020) and California (Cameron et al., 2017), the United States nationally (Fargione et al., 2018), and the world (Griscom et al., 2017). The NCS pathways examined included activities associated with avoided land conversion, land management practices, and restoration (Table 1). In Washington State, the ecosystems of focus included temperate forestlands, shrub-steppe sagebrush lands, agricultural landscapes, riparian forests, and tidal wetlands.

Given the similarity of physiographic, industrial, and socio-economic characteristics of Washington and Oregon, we opted to assess 11 of the 12 pathways in Graves et al. (2020) excluding the sage brush restoration pathway because data are lacking for Washington, and rates of sage brush restoration are low. Griscom et al. (2017) and Fargione et al. (2018) investigated 
127 additional NCS pathways, but we opted not to include these because of their low relevance or 128 low practicality in Washington. The Cascade Mountain Range divides both states into long 129 Pacific Coastlines and wet temperate forests in the west and dry forests and shrub-steppe in the east of the state. Timber, agriculture, and tourism direct these states' rural economies (Spies et al., 2019). However, the lands and waters making up the Puget Sound region, also called Puget Trough, contains a naturally protected inland sea unique to Washington, though many of its terrestrial ecosystems function similarly to coastal ecosystems and western forests of Oregon.

We conducted three effort-level scenarios of future NCS pathway implementation across a 31year period of simulation, applied to a hypothetical timeframe of 2020 through 2050 . However, we recognize that actual deployment will require some years of program development. We calculated reductions annually to quantify potential cumulative $\mathrm{CO}_{2}$ e reductions over that period.

The three effort scenarios - Limited, Moderate, and Ambitious - highlight the potential for each pathway to reduce GHG emissions under different intensities of implementation relative to the variability of the pathway's existing baseline rate of change, or historical variation. Scenarios differ by the degree to which implementation rates ramp up in the first decade and level off or continue to increase over the remainder of the 31-year study period (Supplemental Table 1). Applying a ramp-up period represents a strategic approach to work hard at emissions reductions in the near-term so as to not have greater burden as we approach 2050 . For each pathway within each scenario, a feasible implementation rate was determined via stakeholder feedback collected by Graves and colleagues (2020) in Oregon. Given the similarities of the Washington and Oregon timber industry history and socioeconomic changes following Northwest Forest Plan implementation in both states (Grinspoon, Jaworski \& Phillips, 2016), feasibility estimates collected from Oregon stakeholders are reasonable for our study. Importantly, implementation rates of scenarios are meant to illustrate a range of potential outcomes for each NCS pathway.

All scenarios provide additionality, meaning they are equal to the prior year's activity rate plus a calculated future implementation. We assume future implementation of each pathway will occur at some proportion of the historical variation of the pathway (e.g., annual variation of timber harvested from 2003 to 2017). Historical variation is calculated as the baseline annual rate of change times the historical Coefficient of Variation (CV). For pathways with input data provided in annual time series (Deferred Timber Harvest and Replanting After Wildfires), we calculated historical Coefficient of Variation (CV) over the available data years for each county and each region. When the $\mathrm{CV}$ was greater than the amount of activity, we capped the baseline rate at $100 \%$ of the activity to keep from calculating values greater than the available resource. For all other pathways, we assumed a conservative annual historical variation of $10 \%$ in place of the CV.

Scenarios for each pathway can be generalized as follows (see Supplemental Table 1 for a more detailed description). The Limited scenario can be generalized as a steady increase by $10 \%$ of the historical variation each year, with growth reaching $100 \%$ of that historical variation after ten years of implementation and then remaining at $100 \%$ through the last twenty years (Supplemental Tables S2 and S3). Moderate and Ambitious scenarios are generally characterized as the historical variation times a scenario growth coefficient for each pathway to reach a target rate during the first decade and then holding at or continuing to increase from that rate through the second and third decade (Supplemental Tables S2 and S3). The initial growth coefficients ramp up implementation for the first ten years and are then replaced by lower growth coefficients 
171 or simply by the baseline rate, depending on the pathway, to simulate leveling off of the

172 implementation rate during subsequent years.

173 We used Monte Carlo simulations to model the range of potential emissions reductions for all 174 combinations of each county, NCS pathway (and sub-activity when necessary), simulation year,

175 sequestration or avoided emissions rate, and implementation scenario (Supplementary Tables S4-

176 S9). The simulations sample 1000 iterations from a distribution created with the uncertainty

177 range (i.e. standard deviation of sequestration or emission rate) for the pathway. All simulations

178 and analyses were conducted using the software R (version 3.4.1) (Supplemental Code S10 and

179 S11).

180 NCS Pathways

181 The following are generalized descriptions of the methods we used for each pathway. Pathways

182 are organized under three themes: Land Management, Avoided Conversion, and Restoration.

183 Detailed descriptions of the methods are provided in Graves et al. (2020), Supplemental Tables

184 S1-S3, and Supplemental Code S10. We ran all three scenarios for each pathway.

185 Land Management Pathways

186 Extending Timber Harvest Rotations: We estimated business-as-usual annual carbon

187 emissions with timber harvest data for each forest ownership in Washington from 2003 to 2017

188 (WDNR, 2018). Our assumed harvest deferral is from a 45-year rotation to a 75-year rotation to

189 maximize sequestration potential from tree growth (Curtis, 1995). We performed calculations

190 separately for areas east and west of the Cascade Mountain Range to address known productivity

191 differences (Latta, Temesgen \& Barrett, 2009) and excluded counties where wildfire risk was

192 considered high or extreme on more than 50\% of forestland (Gilbertson-Day et al., 2018) to limit

193 influence of fire on carbon stocks. We also did not assess tribal lands in our analysis because

194 their harvest volumes were not included in the published timber harvest reports.

195 To capture net carbon flux of this pathway, we calculated sequestration and emissions associated

196 with harvest volume, below-ground biomass, unused mill residues, wood as commercial fuel,

197 and short-lived ( $\leq 20$-years) transformed wood products, as described in Graves et al. (2020). We

198 developed these rates each for wet and dry dominated forests, west and east of the Cascades

199 Mountain Range respectively. For delayed harvest scenarios, we also calculated added

200 sequestration which occurs at higher rates on delayed harvest stands than on recently harvested

201 stands of private-owned, even-aged managed forests (Smith et al., 2006). We used Monitoring

202 Trends in Burn Severity (MTBS) fire perimeters (Finco et al., 2012) to filter out forest cover loss

203 from wildfire and used growth tables for regional forests after clearcuts (Smith et al., 2006) to

204 estimate differences in carbon sequestration in even-aged managed forests. We calculated

205 baseline rates of clearcutting where private land boundaries intersect forest change data during

206 the period 2000 to 2016 (Hansen et al., 2013), version 1.5.

207 Because Washington defines categories of private ownership differently than Oregon, we

208 departed from Graves et al. in that we combined private industrial and private non-industrial 209 forest ownerships into a single sub-activity. We therefore changed the scenario implementation

210 rates to reflect this. Based on discussion with natural resource managers, we selected maximum

211 possible implementation to be limited to $40 \%$ on private lands for the Ambitious scenario as a

212 compromise between the percentages used by Graves et al. for private non-industrial forests

$213(100 \%)$ and private industrial forests (21\%). As we do not distinguish these two owner types, we

Peer) reviewing PDF | (2021:03:59450:2:0:NEW 25 Jun 2021) 
214 chose to apply a value of $40 \%$ which largely biases towards the industrial. For state lands, we

215 used the $32 \%$ used by Graves et al. Implementation is allowed to reach $100 \%$ on all other

216 ownerships in western Washington counties and for all ownerships in eastern counties. After the

217 first decade, the implementation holds at the maximum rates achieved in the first decade.

218 The Moderate scenario increases annually for the first decade by an amount equal to $10 \%$ of a

219 percentage of the historical variation, reaching $100 \%$ of that allowed growth at ten years. These

220 percentages are $30 \%$ of the baseline rate on private ownerships, $15 \%$ on state, and $75 \%$ on

221 federal and other. During the last two decades, the rate holds steady at the maximum rate

222 achieved over the first decade.

223 The Limited scenario differs in that it increases annually for the first decade by an amount equal

224 to $10 \%$ of the historical variation, and then it drops and stabilizes at half the historical variation

225 for the remaining twenty years. In some cases, the Limited scenario can result in emissions

226 reductions greater than those of the Moderate scenario in a given year depending on the

227 Moderate scenario's proportional growth coefficient and the CV for the pathway's baseline

228 activity.

229 Agricultural Practices: To prevent deemphasis of the potential contribution of agriculture to

230 NCS in Washington, we present Agricultural Practices as a single pathway though we calculated

231 it as the sum of three separate sub-activities: applying cover crops, no-till practices, and nutrient

232 management. The sub-activities were calculated independently of each other and do not simulate

233 interactions between them that could potentially reduce or amplify GHG emissions, but we

234 assume they will be applied with deliberate attention to address those interactions.

235 For cover crops, we estimated baseline rates of cover crop application with the 2012 and 2017

236 Census of Agriculture county-level data (USDA NASS, 2019a). Where county-level data were

237 not made available, we calculated each of those county's cover crop areas using the difference of

238 the statewide reported cover crop area and the total proportion of that difference relative to the

239 area reported for the other year. The area of maximum possible implementation is equal to the

240 reported cropland area without cover crops, and crop type is not specified. We assume cover

241 crops can be applied to all croplands, though we recognize this likely is not the case. The

242 maximum possible implementation area was not reached in our scenarios.

243 Similarly, for no-till agricultural practices, we estimated baseline rates of no-till agriculture with

244 data from the 2012 and 2017 Census of Agriculture county-level data (USDA NASS, 2019a).

245 The area of maximum possible implementation is equal to the reported cropland area managed

246 with tilling. Like cover crops, we assume no-till practices can be applied to all croplands

247 although this is unlikely in practice. The maximum possible implementation area was not

248 reached in our scenarios.

249 To calculate the nutrient management activity, we used published methods to produce county-

250 level estimates of $\mathrm{N}$ fertilizer application, combining fertilizer sales and reported fertilizer

251 chemical composition to convert tons of product sold to $\mathrm{kg}$ of $\mathrm{N}$ per county (Ruddy, Lorenz \&

252 Mueller, 2006; AAPFCO, 2014). This estimate disaggregates agricultural and other fertilizer

253 uses. To maintain consistency with Graves et al. (2020), we use 40\% of croplands as the

254 maximum possible area of reduced fertilizer application.

255 Avoided Conversion

Peer] reviewing PDF | (2021:03:59450:2:0:NEW 25 Jun 2021) 
256

257

258

259

260

261

262

263

264

265

266

267

268

269

270

271

272

273

274

275

276

277

278

279

280

281

282

283

284

285

286

287

288

289

290

291

292

293

294

295

296

297

298

299

Conversion of forests to development: We estimated the baseline rate of forest conversion on private land by intersecting land use data layers from 1994 and 2013, calculating conversion as the sum of two separate activities: from forests to urban (complete loss) and from forests to rural (partial loss) land uses (Gray et al., 2013, 2016). We grouped counties into east and west of the Cascade Mountain Range to address uncertainty in pre-conversion carbon stocks and sequestration.

Sagebrush-steppe conversion to invasive annual grasses: To estimate current rates of burnassociated conversion of sagebrush-steppe to invasive annual grasses, we combined the areal extent of fires from 1984 to 2014 (U.S. Geological Survey, 2018) with the annual grass dominance (U.S. Geological Survey, 2016). Background level of invasion by annual grasses is the proportion of burned areas dominated by invasive annual grasses minus the proportion of invasive annual grass-dominated land outside of burned areas.

Grassland conversion to cropland: We calculated rate of grassland loss in Washington from the 15,681 acres of land uncultivated since the 1970s which were retained or restored to grassland and subsequently converted to cropland between 2008 and 2012 (Lark, Salmon \& Gibbs, 2015). Lacking county-level statistics, we used Lark et al. (Lark, Salmon \& Gibbs, 2015) methods to classify grasslands with the 2012 USDA Cropland Data Layer (USDA NASS, 2019b), and then we calculated per county baseline conversion rates as proportional to the county's percent of statewide grassland area.

\section{Restoration}

Riparian reforestation: We estimated the annual rates of riparian forest restoration using data on reported riparian restoration tree plantings from 1999 to 2015. The Washington Conservation Enhancement Reserve Program (CREP) 2015 monitoring summary report (Cochrane, 2016) served as our primary data source, and we supplemented this with acreage of riparian planting by county from the Washington State Recreation and Conservation Office PRISM (PRoject Information SysteM) database (WRCO, 2019). Because there is no mandatory system for reporting riparian reforestation efforts across Washington, we likely undercalculate the baseline riparian reforestation rate. Washington's sequestration rate for riparian reforestation was derived as a weighted average of coastal and interior sequestration rates, where weights were calculated as the spatial distribution of efforts reported in the PRISM database. We assume a similar effort of implementation between PRISM and CREP in Washington.

Replanting after fires: We estimated the current level of replanting effort on US Forest Service and US Bureau of Land Management lands post-wildfire and quantified the $\mathrm{C}$ sequestration benefits from replanting versus natural regeneration on those lands (Smith et al., 2006). The baseline for replanting on Federal land was determined by examining current patterns of replanting after wildfire. In areas defined as high burn severity, the baseline rate is $0 \mathrm{ha}^{\mathrm{yr}-1}$, as no replanting is occurring in these areas (U.S. Bureau of Land Management, 2018; U.S. Forest Service, 2019). Sequestration rates were calculated on a per year basis to simulate changes in growth rates over time.

Tidal wetland restoration: We used tidal wetland restoration areas and lost (converted) tidal wetland areas to estimate a baseline rate of restoration in most counties (PSMFC GIS, 2017; Ramirez, 2019). We assumed all lost tidal wetland area to have restoration potential, an area totaling 47,000 ha statewide, and each county's potential restoration area was capped at its lost wetland area. We also assumed no further wetland loss will occur. In Puget Sound counties 
300 where tidal wetland restoration was not known or mapped in the restoration data, we assumed 301 some restoration will occur in the future. We assigned each of those counties a restoration rate 302 equal to its lost tidal wetlands hectares times a constant 0.00215 , where that constant is the 303 proportion of the statewide lost tidal wetland area that was restored annually in the Puget Sound 304 during the baseline period. To estimate restoration rates in Pacific County, where known projects 305 were not included in the input dataset, we obtained and inserted restoration areas described by 306 the U.S. Fish \& Wildlife Service (2015).

307

308

\section{Washington State}

310 We estimate that NCS has potential to achieve an emissions rate of $-8.8 \mathrm{MMT} \mathrm{CO}_{2} \mathrm{e}^{\mathrm{yr}-1}$ in 31 311 years under an Ambitious pathway (Table 2). This is approximately $8.9 \%$ of theannual emissions 312 reductions needed in Washington to achieve carbon neutrality by the year 2050 (assuming the 313 baseline emissions rate from 2018 and start date of 2020). Of this $8.9 \%$ reduction, extending 314 timber harvest rotations has the largest potential contribution (64\%), followed by combined 315 agricultural practices (16\%) and avoided conversion of forests (13\%).

316 Our results demonstrate that Moderate and Limited scenarios offer pathways for reducing 317 statewide emissions by approximately $5.1 \%$ and $4.3 \%$ respectively. Like the Ambitious scenario, 318 extending timber harvest rotations, instituting different agricultural practices, and avoiding forest 319 conversion make up the top pathways of these two scenarios. (Annual results of each 320 combination of pathway, scenario, and geography - county and statewide - are in Supplemental 321 Tables S4-S8.)

\section{Geographic patterns}

323 Potential NCS reductions are unevenly distributed across Washington (Fig 1). Extending timber 324 harvest rotations drives the spatial concentration of potential reductions toward coastal and 325 southwest counties with large private timber ownership. Indeed, under the Ambitious scenario, 326 that pathway's $-0.6 \mathrm{MMT} \mathrm{CO}_{2}$ e potential 2050 reductions in Lewis County alone are greater than 327 the highest aggregated reductions from all other pathways in any single county. Excluding the 328 Extended Timber Harvest Rotations pathway, Grant County has the highest aggregated 329 reductions, which are largely driven by cover crop and no-till activities in the Cropland 330 Agriculture pathway and total $-0.2 \mathrm{MMT} \mathrm{CO}_{2}$ e potential reductions in 2050.

331 While the maximum potential $\mathrm{CO}_{2} \mathrm{e}$ reductions achievable via extending timber harvest rotations 332 (and thus total NCS) is located in Washington's western coastal counties, the maxima of other 333 NCS pathways occurs in other regions of the state (Fig. 2). For instance, the maximum for the 334 Avoided Conversion of Forests pathway occurs in the urbanizing Puget Sound region, and the 335 greatest opportunities for the Cropland Agricultural Practices pathway is in agricultural regions 336 in eastern Washington (Fig. 2). 
337 The greatest NCS gains can be clustered into three geographically concentrated resource-specific

338

339

340

341

342

343

344

345

346

347

348

349

350

351

352

353

354

355

356

357

358

359

360

361

362

363

364

365

366

367

368

369

370

371

372

373

374

social-ecological systems: private industrial timber in southwestern wet forests, cropland agriculture in the Columbia Plateau and Palouse Prairie, and suburban development and urban sprawl in central Puget Sound (Fig. 3). Private industrial timber drives the Extended Timber Harvest Rotations pathway, with over half the emissions reductions potential in southwestern wet forests (plus the highly industrial forests of Stevens County in the northeast.) The second highest NCS reductions are found through Cropland Agricultural Practices pathway, with nearly half of its reduction potential in four eastern Washington counties. The Avoided Conversion of Forests pathway provides the third highest potential reductions with nearly half being clustered in five of Puget Sound's fastest growing counties marked by suburban and rural development.

\section{Discussion}

Our estimates of the potential $\mathrm{CO}_{2} \mathrm{e}$ reductions with NCS ranged from 4.3 to $8.8 \mathrm{MMT} \mathrm{CO}_{2} \mathrm{e}$ by the $31^{\text {st }}$ year of implementation, depending on the aggressiveness of our scenarios. These values are similar to the 2.9 to $9.8 \mathrm{MMT} \mathrm{CO}_{2} \mathrm{e}$ at the $31^{\text {st }}$ year estimated by Graves et al. (2020) for Oregon and highlight the potential for NCS to contribute to atmospheric carbon sequestration efforts. Our results reveal that an ambitious implementation of NCS has the potential to achieve up to $8.9 \%$ of Washington's net zero goal by 2050 , with much of these gains achieved by extending timber harvest rotations. However, the three major pathways - Extended Timber Harvest Rotations, Cropland Agriculture, and Avoided Forest Conversion, have vastly different reduction potentials depending on where they are implemented across the state.

Similar to studies in other western U.S. states, such as Oregon and California (Cameron et al., 2017; Graves et al., 2020), we found that extending harvest rotations on industrial forestlands in Washington's wet forests offered the largest NCS contribution. Although current industrial forest management is focused on short-term capital gains (Lacy, 2006), we demonstrate that extending timber harvest rotations could have significant reductions in Washington's GHG emissions, a finding that aligns with evidence showing that large trees disproportionately drive forest carbon cycle dynamics (Mildrexler et al., 2020). These reductions would likely supplement a list of cobenefits including improved water quality, improved summer baseflows, wildlife habitat, and salmon productivity.

Cropland agricultural pathways, such as cover crops, no-till agriculture, and nutrient management, offer the greatest climate mitigation potential for NCS in the eastern half of Washington where highly productive and extensive croplands are found. Historically, nutrientrich shrub steppe and grassland ecosystems dominated these current agricultural landscapes due to frequent wildfires and a dry continental climate which limit forest productivity.

Our study also shines a spotlight on the substantial threat of land-use change and forest conversion in the rapidly growing Puget Trough, driven by a growing technology industry and the desire for affordable housing. However, recent analysis by the Washington Department of

Peer) reviewing PDF | (2021:03:59450:2:0:NEW 25 Jun 2021) 
375 Fish \& Wildlife and the Puget Sound Partnership found that conversion of forest cover loss to 376 development has declined considerably and continuously in the region since 1991 (Pierce, Jr. et 377 al., 2017; Puget Sound Partnership, 2020). The cause of this decline is not well understood, but 378 slowdowns of development due to economic downturns and other possibly temporary factors 379 may indicate that development and therefore conversion rates could increase with further 380 economic growth. If the existing declining trend in forest conversion rates continues, this study 381 may over-calculate the NCS potential of avoiding forest conversion in Washington State, though 382 the net emissions reductions would likely still occur with or without implementing NCS under 383 our scenarios.

\section{Spatial Patterns}

385

386

387

388

389

390

391

392

393

394

395

396

397

398

399

400

401

402

403

404

405

406

407

408

409

410

411

412

413

Three factors drive the spatial patterns we report; 1) spatial extent of ecosystems; 2) abundance and productivity of vegetation; and, 3) land ownership. Extensive forest ecosystems across Washington State mean that NCS pathways that involve forest management could contribute substantially to NCS potential simply due to scale. It is thus not surprising that, combined, forest strategies (extending timber harvest rotations, forest avoided conversion, riparian reforestation, and post-wildfire replanting) contribute over $80 \%$ of the NCS potential in Washington State. Our Tidal Wetland Restoration results further demonstrate that natural ecosystem size strongly influences NCS sequestration potential. The Tidal Wetland Restoration pathway has its greatest potential for emissions reductions where restorable wetland area is currently large in spatial scale, such as the large estuarine deltas of eastern Puget Trough and southwest coastal Washington counties. By contrast, topographically constrained estuaries in the western Puget Trough and along the Olympic coast are smaller in size and therefore have lower NCS potential.

Geologic and climatic patterns drive the composition, abundance, and productivity of vegetation, thereby influencing the potential of NCS across Washington. While some regions, such as the moist forests along the coast are characterized by highly productive forests and high rates of carbon sequestration, dry areas of the state have less productive forests and are at high risk of wildfire. By excluding counties with high wildfire risk from our extended timber harvest rotations analysis, the geographic pattern is focused on counties with high productivity and low fire risk to west of the Cascade Mountain Range. Cropland agricultural pathways show distinct patterns as well, focusing where historically available water and fertile soils promote productive cropland in valleys of eastern Washington and floodplains of the Puget Trough.

Land ownership is a third major driver of geographic patterns. In Washington, public lands have low risk of forest conversion (Gray et al., 2013), and major changes to public forest management are limited by policy restrictions on federally-owned forests (Spies et al., 2019) and legally bound fiduciary obligations in the case of State Forest Lands trust (Washington Department of Natural Resources, 2021). Thus, potential for additional emissions reductions is generally highest in counties with large private ownership of forests such as Lewis and Stevens Counties. For those same reasons, counties with little private forest ownership likely will have lower relative NCS potential even if they have vast public forest ownership, such as Jefferson and Whatcom 
414 Counties with large state forests, US Forest Service ownership, and the Olympic and North 415 Cascades National Parks respectively. This is particularly evident in Puget Trough counties, 416 where remaining forests are generally public-owned. However, the remaining privately owned 417 Puget Trough forests are more profitable for suburban development than for logging. As a result, 418 the Avoided Conversion of Forests pathway holds its greatest potential in those Puget Trough 419 counties.

\section{Success and Challenges}

421 Success of a net zero goal likely requires individuals and decision-makers to redefine their 422 notions of practicality, considering many pathways as courageous enterprises rather than 423 unfeasible concepts. Even mitigation pathways that sequester relatively small amounts of carbon

424

425

426

427

428

429

430

431

432

433

434

435

436

437

438

439

440

441

442

443

444

445

446

447

448

449

450

451

452 should be considered for at least two reasons. First, every small reduction will be necessary to approach net zero emissions, and negative emissions could help offset other states that do not achieve net zero emissions. Second, all pathways have co-benefits, and these co-benefits may contribute to climate adaptation and resilience in a region.

The scale at which decisions are made can inhibit the effective implementation and outcomes of climate mitigation strategies. Extensive actions addressing climate mitigation may be impeded by social and cultural differences as well as differences in lived experiences that are not considered in the broad-scale top-down decision-making approaches (Landauer, Juhola \& Klein, 2019; Nightingale et al., 2020). Additionally, conflicting policy-objectives among different scales of governance can hinder adoption of broad-scale climate mitigation measures.

Furthermore, the large scales at which mitigation is often discussed can be disconnected from the local scale of adaptation. Such separation may thwart efforts to build local support for mitigation and distances government accountability for addressing local needs (Nightingale et al., 2019).

The need for multiple solutions to the climate crisis is clear, and thus NCS should not be considered as an alternative to other carbon mitigation strategies (Anderson et al., 2019). While forest restoration and afforestation may be highly effective strategies for mitigating climate change (Bastin et al., 2019), these strategies alone cannot adequately nullify emissions from fossil-fuels and other anthropogenic GHGs at a global scale (Anderson et al., 2019; Friedlingstein et al., 2019). Indeed, our results highlight the potential for improved management of ecosystems and natural resources to provide greatest net emissions reductions among NCS pathways in Washington State. Also, while the costs of NCS can be low relative to other strategies (Griscom et al., 2017), a number of constraints can diminish practicality and effectiveness of natural solutions, such as political interests, local economic factors, varying scales of decision-making, deployment time, and undesired collateral effects such as resource leakage and biophysical changes in the environment (Nesshöver et al., 2017; Landauer, Juhola \& Klein, 2019; Friedlingstein et al., 2019; Mulligan et al., 2020).

Logistics of NCS deployment and concerns about economic losses by industries and communities may also stall implementation of NCS. For example, an argument might be made that the economic cost of extending harvest rotations is too great, rendering this NCS pathway 
453 infeasible. Moreover, extending timber rotations can disrupt markets and undermine NCS 454 benefits if the equivalent carbon sequestration is lost through harvesting elsewhere (i.e., leakage). 455 Although leakage may limit this pathway's practicality (Mulligan et al., 2020), in the Pacific 456 Northwest leakage has been shown to be relatively small when compared to the substantial 457 amount of carbon stored through improved forest management and embodied carbon in wood 458 products (Diaz et al., 2018). While there is no doubt that implementation of this pathway may be 459

460

461

462

463

464

465

466

467

468

469

470

471

472

473

474

475

476

477

478

479

480

481

482

483

484

485

486

487

488

489

490

491 challenging, even under our Ambitious scenario, only up to $40 \%$ of private timber harvest is subjected to lengthened harvest rotations, and many counties do not reach that maximum in our analysis. Thus, the utility of lengthening timber harvest rotations may be greater in Washington than in other locations.

The effects of leakage with NCS is a key consideration. All pathways have potential for leakage if not implemented appropriately, and NCS in theory and in practice should address this challenge. Just as NCS forest management needs to account for possible losses of carbon sequestered by other forests that may be logged to meet the demand for timber, agricultural practices and wetland restoration need to account for possible reductions in crop production that may increase elsewhere to meet market demand, thus diminishing mitigation gains. The inherent nature of agricultural management pathways for carbon is that they should retain or increase crop productivity through improvements to soil health, water efficiency, and other advantages (Dabney et al., 2010). While there are many challenges in implementing NCS, these obstacles may be relieved by cost efficiencies and other advantages arising from the focused spatial patterns, concentrated business sectors, and industry clusters associated with NCS pathways. Efficiencies and co-benefits might also be maximized when addressing multiple overlapping pathways in a region with a whole systems approach. Certainly, this is the case for sub-activities of the Cropland Agriculture pathway, where carbon benefits can be best realized through simultaneous management interventions that increase no-till cover crop practices and decrease N-fertilizer application (Stöckle et al., 2012; Beach et al., 2018; Schmidt et al., 2018).

With limited resources and regionalized economies, our results highlight that a fruitful way forward may be to deploy NCS at a county scale. With county-level information, state decisionmakers can focus attention on regional issues and include local stakeholders in a manner that may be impractical statewide. As a result, appropriate program incentives addressing sociocultural sensitivity, economic development, and ecological protections can be catered to the needs of specific communities and industries. In turn, those local stakeholders can work with state decision-makers to develop ecological and human resilience plans in concert with mitigation activities. The success of the local climate planning approach to climate policy implementation and achievement of implementation goals has yet to be widely studied, but early investigations from the European Union suggest climate change issues are best tackled by either 1) developing dedicated local plans in parallel with larger scale mainstream plans, or 2) starting with a dedicated local plan and subsequently developing a mainstream plan (Reckien et al., 2019). 
492 Further research should look at the value per unit of pathway implementation to plan for the most

493 cost-effective and optimal outcomes of implementing multiple pathways within a county. A

494 simple calculation of mitigation potential per county area may provide a starting point

495 (Supplemental Table S9), but calculating the implementation per available resource quantity

496 within the county could provide better means for prioritizing pathway deployment.

\section{Multiple Benefits of NCS}

498 Despite real and potential benefits of NCS for climate change mitigation, NCS could be of

499

500

501

502

503

504

505

506

507

508

509

510

511

512

513

514

515

516

517

518

519

520

521

522

523

524

525

526

527

528

529

530

greater service for climate resilience and other co-benefits (Griscom et al., 2017; Seddon et al., 2019) when implemented to avoid negative or unintended consequences (Hashida et al., 2020).

For example, numerous human health, social equity, and ecological benefits exist from reduced $\mathrm{N}$ fertilizer use. Nitrates from fertilizer seep into groundwater, contaminating human drinking water reservoirs (Keeler \& Polasky, 2014). This nitrate contaminated water has been linked directly to high cancer rates, low fertility rates, increased water treatment costs, and devaluation of property in rural communities, including in Washington (Townsend et al., 2003; Dubrovsky et al., 2010; Moore et al., 2011; Keeler \& Polasky, 2014). Likewise, reduction of N fertilizer use has benefits for marine and freshwater biota and soil health (Culman et al., 2010; Dubrovsky et al., 2010). NCS can generate multiple benefits when implemented in concert across whole systems. We found that much of the greatest emissions reduction potential by three pathways (Avoided Conversion of Forest, Riparian Restoration, and Tidal Wetland Restoration) exist in the Puget Trough, particularly overlapping in Snohomish County. The links between the upland forests, river corridors, floodplains, and estuaries are important ecologically, culturally, socially, and economically. From an ecological perspective, Chinook salmon (Oncorhynchus tshawytscha) are listed under the U.S. Endangered Species Act and vital to the health of many freshwater and riparian ecosystems in the Pacific Northwest (Willson \& Halupka, 1995). Chinook salmon use the full Snohomish River system, spawning in upland streams, rearing in mainstem floodplain and estuarine channels, feeding in nearshore marine waters, and migrating back upstream to spawn. These life stage requirements thus link Chinook salmon to the Avoided Conversion of Forest, Riparian Restoration, and Tidal Wetland Restoration NCS pathways. Upland forests help control stream flashiness and sedimentation, which can inhibit spawning and rearing (Beechie et al., 2013). Riparian tree cover cools streams, provides refugia along riverbanks, and delivers terrestrial insect food resources (Seavy et al., 2009; Beechie et al., 2013). High productivity tidal wetlands provide juvenile Chinook with the low salinity habitat they need to transition from fresh to saltwater living, as well as the saltmarshes which provide energy-rich food resources critical to early marine survival for juvenile Chinook (Simenstad \& Cordell, 2000; David et al., 2014). Chinook salmon are also an important cultural and nutritional resource to the indigenous Coast Salish peoples, and fishing of the Chinook is an intrinsic right legally affirmed by the US Supreme Court's 1974 Boldt Decision (United States v. Washington, 1974). In addition to improving conditions for Chinook Salmon, these three pathways may provide other co-benefits such as mitigation for flooding of croplands and homes downstream,

Peer] reviewing PDF | (2021:03:59450:2:0:NEW 25 Jun 2021) 
531 and improved water quality associated with sedimentation, nutrification, and fecal pathogens 532 (DeGasperi et al., 2018).

533

\section{Conclusions}

535 Natural Climate Solutions have the potential to play a significant part in climate change

536 mitigation. Our findings show that NCS can assist in achieving a Net Zero goal by 2050 in Washington, and those achievements range by the aggressiveness of NCS pathway implementation. Further research assessing costs and practicality of NCS and the ongoing impacts of climate change will yield additional insight that could influence the feasibility of NCS

540 pathways. Likewise, rigorous examination of the ecological, social, cultural and health co-

541 benefits of NCS is crucial for assessing the benefit-cost ratio of any pathway.

542 Clearly, a broad portfolio of tools and approaches will be needed to combat climate change.

543 Indeed, to achieve carbon neutrality in Washington by mid-century, NCS pathways may be 544 required even if reductions through changes in transportation, industry, and residential sectors 545 can be achieved. Our work provides needed information that emphasizes the potential scope of 546 NCS to achieve carbon goals as well as the spatial distribution of NCS opportunities. This is the

547

548

549

550

\section{1}

552

553

554

555

556

557

558

\section{9}

560

561

562

563

564

565

566

567 foundation required to generate natural climate solutions that are fair, just and contribute significantly to address climate change in Washington and beyond. Addressing climate change is urgent.

\section{Acknowledgements}

Thanks to Rose Graves, Ryan Haugo, Michael Schindel, and Bryce Kellogg for sharing methods, data, and advice, to Mary Ramirez and Jennifer Burke for sharing data and thoughts on estuary restoration rates, and to Juliana Tadano, Elizabeth Matteri, Chase Puentes, and Pascale Chamberland for literature research. Thanks also to Ailene Ettinger and Kristina Bartowitz for detailed reviews, to Maia Murphy-Williams for facilitating some aspects of this project, and to Mo McBroom for early encouragement and insight.

\section{References}

AAPFCO. 2014. Association of American Plant Food Control Officials, Commercial Fertilizer Reports. Available at https://www.aapfco.org/publications.html (accessed March 18, 2020) Anderson CM, DeFries RS, Litterman R, Matson PA, Nepstad DC, Pacala S, Schlesinger WH, Shaw MR, Smith P, Weber C, Field CB. 2019. Natural climate solutions are not enough. Science 363:933 LP - 934. DOI: 10.1126/science.aaw2741.

Bastin J-F, Finegold Y, Garcia C, Mollicone D, Rezende M, Routh D, Zohner CM, Crowther TW. 2019. The global tree restoration potential. Science 365:76 LP - 79. DOI: 10.1126/science.aax0848. 
568 Beach HM, Laing KW, Walle M V, Martin RC. 2018. The Current State and Future Directions

569

570

571

572

573

574

575

576

577

578

579

580

581

582

583

584

585

586

587

588

589

590

591

592

593

594

595

596

597

598

599

600

601

602

603

604

605

606

607

608

609

610

611

612

613 of Organic No-Till Farming with Cover Crops in Canada, with Case Study Support. Sustainability 10. DOI: 10.3390/su10020373.

Beechie T, Imaki H, Greene J, Wade A, Wu H, Pess G, Roni P, Kimball J, Stanford J, Kiffney P, Mantua N. 2013. Restoring salmon habitat for a changing climate. River Research and Applications 29. DOI: 10.1002/rra.2590.

Bustamante M, Robledo-Abad C, Harper R, Mbow C, Ravindranat NH, Sperling F, Haberl H, Pinto A de S, Smith P. 2014. Co-benefits, trade-offs, barriers and policies for greenhouse gas mitigation in the agriculture, forestry and other land use (AFOLU) sector. Global Change Biology 20. DOI: 10.1111/gcb.12591.

Cameron DR, Marvin DC, Remucal JM, Passero MC. 2017. Ecosystem management and land conservation can substantially contribute to California's climate mitigation goals. Proceedings of the National Academy of Sciences 114:12833 LP - 12838. DOI: 10.1073/pnas.1707811114.

Chrisinger C, Fowler C, Kleit R. 2015. Industry Clusters and Employment Outcomes in Washington State. Economic Development Quarterly 29. DOI: 10.1177/0891242415571126.

Cochrane B. 2016. Implementation, Effectiveness Monitoring and Financial Report for the Washington Conservation Reserve Enhancement Program (CREP) for Federal Fiscal Year 2015. Available at https://www.scc.wa.gov/conservation-reserve-enhancement-program (accessed March 18, 2020)

Culman SW, Young-Mathews A, Hollander AD, Ferris H, Sánchez-Moreno S, O'Geen AT, Jackson LE. 2010. Biodiversity is associated with indicators of soil ecosystem functions over a landscape gradient of agricultural intensification. Landscape Ecology 25:1333-1348. DOI: $10.1007 / \mathrm{s} 10980-010-9511-0$.

Curtis RO. 1995. Extended Rotations and Culmination Age of Coast Douglas-fir: Old Studies Speak to Current Issues. PNW-RP-485. Portland, OR.

Dabney SM, Delgado JA, Meisinger JJ, Schomberg HH, Liebig MA, Kaspar T, Mitchell J, Reeves W. 2010. Using Cover Crops and Cropping Systems for Nitrogen Management. In: Delgado JA, Follett RF eds. Advances in Nitrogen Management for Water Quality. Ankeny, IA, 230-281.

David AT, Ellings CS, Woo I, Simenstad CA, Takekawa JY, Turner KL, Smith AL, Takekawa JE. 2014. Foraging and Growth Potential of Juvenile Chinook Salmon after Tidal Restoration of a Large River Delta. Transactions of the American Fisheries Society 143. DOI: 10.1080/00028487.2014.945663.

DeGasperi CL, Sheibley RW, Lubliner B, Larson CA, Song K, Fore LS. 2018. Stormwater Action Monitoring Status and Trends Study of Puget Lowland Ecoregion Streams: Evaluation of the First Year (2015) of Monitoring Data. Available at https://green2.kingcounty.gov/ScienceLibrary/Document.aspx? ArticleID $=530$ (accessed January 29, 2021)

Diaz D, Loreno S, Ettl G, Davies B. 2018. Tradeoffs in Timber, Carbon, and Cash Flow under Alternative Management Systems for Douglas-Fir in the Pacific Northwest. Forests 9:447. DOI: $10.3390 / \mathrm{f} 9080447$.

Dubrovsky NM, Burow KR, Clark GM, Gronberg JAM, Hamilton PA, Hitt KJ, Mueller DK, Munn MD, Nolan BT, Puckett LJ, Rupert MG, Short TM, Spahr NE, Sprague LA, Wilber WG. 2010. The quality of our Nation's waters-nutrients in the Nation 's streams and 
614

615

616

617

618

619

620

621

622

623

624

625

626

627

628

629

630

631

632

633

634

635

636

637

638

639

640

641

642

643

644

645

646

647

648

649

650

651

652

653

654

655

656

657

658

659

groundwater, 1992 - 2004.

Fargione JE, Bassett S, Boucher T, Bridgham SD, Conant RT, Cook-Patton SC, Ellis PW, Falcucci A, Fourqurean JW, Gopalakrishna T, Gu H, Henderson B, Hurteau MD, Kroeger KD, Kroeger T, Lark TJ, Leavitt SM, Lomax G, McDonald RI, Megonigal JP, Miteva DA, Richardson CJ, Sanderman J, Shoch D, Spawn SA, Veldman JW, Williams CA, Woodbury PB, Zganjar C, Baranski M, Elias P, Houghton RA, Landis E, McGlynn E, Schlesinger WH, Siikamaki J V, Sutton-Grier AE, Griscom BW. 2018. Natural climate solutions for the United States. Science Advances 4:eaat1869. DOI: 10.1126/sciadv.aat1869.

Finco M, Quayle B, Zhang Y, Lecker J, Megown K a., Brewer CK. 2012. Monitoring Trends and Burn Severity (MTBS): Monitoring wildfire activity for the past quarter century using LANDSAT data. Available at https://www.fs.usda.gov/treesearch/pubs/42750

Friedlingstein P, Allen M, Canadell JG, Peters GP, Seneviratne SI. 2019. Comment on "The global tree restoration potential.” Science 366:eaay8060. DOI: 10.1126/science.aay8060.

Gilbertson-Day JW, Scott JH, Vogler KC, Brough AM, Stratton R. 2018. Pacific Northwest Quantitative Wildfire Risk Assessment: Methods and Results. Available at http://pyrologix.com/downloads/ (accessed March 18, 2020)

Graves RA, Haugo RD, Holz A, Nielsen-Pincus M, Jones A, Kellogg B, Macdonald C, Popper K, Schindel M. 2020. Potential greenhouse gas reductions from Natural Climate Solutions in Oregon, USA. PLOS ONE 15:e0230424. DOI: 10.1371/journal.pone.0230424.

Gray AN, Azuma DL, Lettman GJ, Thompson JL, McKay N. 2013. Changes in land use and housing on resource lands in Washington State, 1976-2006. USDA Forest Service - General Technical Report PNW-GTR:1-51. DOI: 10.2737/PNW-GTR-881.

Gray A, Hubner D, Lettman GJ, McKay N, Thomspson JL. 2016. Forests, farms \& people: Land use change on non-federal land in Oregon 1974-2014. Available at https://inr.oregonstate.edu/biblio/forests-farms-people-land-use-change-non-federal-landoregon-1974-2014 (accessed March 18, 2020)

Grinspoon E, Jaworski D, Phillips R. 2016. Northwest Forest Plan — the first 20 years (19942013): social and economic status and trends. Report FS/R6/PNW/2015/0006. Available at https://www.fs.fed.us/r6/reo/monitoring/downloads/socioeconomic/Nwfp20yrMonitoringRe portSocioeconomic.pdf (accessed March 15, 2021)

Griscom BW, Adams J, Ellis PW, Houghton RA, Lomax G, Miteva DA, Schlesinger WH, Shoch D, Siikamäki J V, Smith P, Woodbury P, Zganjar C, Blackman A, Campari J, Conant RT, Delgado C, Elias P, Gopalakrishna T, Hamsik MR, Herrero M, Kiesecker J, Landis E, Laestadius L, Leavitt SM, Minnemeyer S, Polasky S, Potapov P, Putz FE, Sanderman J, Silvius M, Wollenberg E, Fargione J. 2017. Natural climate solutions. Proceedings of the National Academy of Sciences 114:11645 LP - 11650. DOI: 10.1073/pnas.1710465114.

Gupta J. 2010. A history of international climate change policy. Wiley Interdisciplinary Reviews: Climate Change 1. DOI: 10.1002/wcc.67.

Hansen MC, Potapov P V., Moore R, Hancher M, Turubanova SA, Tyukavina A, Thau D, Stehman S V., Goetz SJ, Loveland TR, Kommareddy A, Egorov A, Chini L, Justice CO, Townshend JRG. 2013. High-resolution global maps of 21 st-century forest cover change. Science. DOI: 10.1126/science.1244693.

Hashida Y, Withey J, Lewis DJ, Newman T, Kline JD. 2020. Anticipating changes in wildlife habitat induced by private forest owners' adaptation to climate change and carbon policy. PLOS ONE 15:e0230525.

IPCC. 2018. Global Warming of $1.5^{\circ} \mathrm{C}$. An IPCC Special Report on the impacts of global

Peer] reviewing PDF | (2021:03:59450:2:0:NEW 25 Jun 2021) 
660

661

662

663

664

665

666

667

668

669

670

671

672

673

674

675

676

677

678

679

680

681

682

683

684

685

686

687

688

689

690

691

692

693

694

695

696

697

698

699

700

701

702

703

704

705

warming of $1.5^{\circ} \mathrm{C}$ above pre-industrial levels and related global greenhouse gas emission pathways, in the context of strengthening the global response to the threat of climate change,. Available at https://www.ipcc.ch/sr15/download/\#full (accessed April 15, 2020)

Keeler BL, Polasky S. 2014. Land-use change and costs to rural households: A case study in groundwater nitrate contamination. Environmental Research Letters 9. DOI: 10.1088/17489326/9/7/074002.

Klinsky S, Roberts T, Huq S, Okereke C, Newell P, Dauvergne P, O’Brien K, Schroeder H, Tschakert P, Clapp J, Keck M, Biermann F, Liverman D, Gupta J, Rahman A, Messner D, Pellow D, Bauer S. 2017. Why equity is fundamental in climate change policy research. Global Environmental Change 44. DOI: 10.1016/j.gloenvcha.2016.08.002.

Lacy P. 2006. Forest investment: the emergence of timberland as an asset class. Australian Forestry 69:151-155. DOI: 10.1080/00049158.2006.10674995.

Landauer M, Juhola S, Klein J. 2019. The role of scale in integrating climate change adaptation and mitigation in cities. Journal of Environmental Planning and Management 62:741-765. DOI: 10.1080/09640568.2018.1430022.

Lark TJ, Salmon JM, Gibbs HK. 2015. Cropland expansion outpaces agricultural and biofuel policies in the United States. Environmental Research Letters 10:44003. DOI: 10.1088/1748-9326/10/4/044003.

Latta G, Temesgen H, Barrett TM. 2009. Mapping and imputing potential productivity of Pacific Northwest forests using climate variables. Canadian Journal of Forest Research 39:11971207. DOI: 10.1139/X09-046.

Mildrexler DJ, Berner LT, Law BE, Birdsey RA, Moomaw WR. 2020. Large Trees Dominate Carbon Storage in Forests East of the Cascade Crest in the United States Pacific Northwest. Frontiers in Forests and Global Change 3:127.

Moore E, Matalon E, Pacific Institute (Oakland C., Community Water Center., Clean Water Fund (Washington DC., California Rural Legal Assistance Foundation. 2011. The human costs of nitrate-contaminated drinking water in the San Joaquin Valley. Pacific Institute.

Mulligan J, Rudee A, Lebling K, Levin K, Anderson J, Christensen B. 2020. CarbonShot: Federal Policy Options for Carbon Removal in the United States. Available at www.wri.org/publication/carbonshot-federal-policy-options-for-carbon-removal-in-theunited-states (accessed January 5, 2021)

Nesshöver C, Assmuth T, Irvine KN, Rusch GM, Waylen KA, Delbaere B, Haase D, JonesWalters L, Keune H, Kovacs E, Krauze K, Külvik M, Rey F, van Dijk J, Vistad OI, Wilkinson ME, Wittmer H. 2017. The science, policy and practice of nature-based solutions: An interdisciplinary perspective. Science of the Total Environment. DOI: 10.1016/j.scitotenv.2016.11.106.

Nightingale AJ, Eriksen S, Taylor M, Forsyth T, Pelling M, Newsham A, Boyd E, Brown K, Harvey B, Jones L, Bezner Kerr R, Mehta L, Naess LO, Ockwell D, Scoones I, Tanner T, Whitfield S. 2020. Beyond Technical Fixes: climate solutions and the great derangement. Climate and Development 12:343-352. DOI: 10.1080/17565529.2019.1624495.

Pierce, Jr. KB, Miller J, Samson K, Quinn T. 2017. A Comparison of Land Development and Cover Vital Sign Indicators as generated from Landsat and NAIP data, Deliverable 2.2 under Contract IAA 2016-23 with the Puget Sound Partnership. Olympia, WA: Washington Department of Fish \& Wildlife.

PSMFC GIS. 2017. Indirect Assessment of West Coast USA Tidal Wetland Loss. Available at http://www.pacificfishhabitat.org/data/ (accessed March 19, 2020)

Peer] reviewing PDF | (2021:03:59450:2:0:NEW 25 Jun 2021) 
706

707

708

709

710

711

712

713

714

715

716

717

718

719

720

721

722

723

724

725

726

727

728

729

730

731

732

733

734

735

736

737

738

739

740

741

742

743

744

745

746

747

748

749

750

751

Puget Sound Partnership. 2020. Rate of Forest Loss to Development. Available at https://www.pugetsoundinfo.wa.gov/ProgressMeasure/Detail/19/VitalSigns (accessed December 10, 2020)

Ramirez M. 2019. Tracking Estuarine Wetland Restoration in Puget Sound; Reporting on the Puget Sound Estuaries Vital Sign Indicator. Available at https://www.pugetsoundinfo.wa.gov/ProgressMeasure/Detail/11 (accessed March 19, 2020)

Reckien D, Salvia M, Pietrapertosa F, Simoes SG, Olazabal M, De Gregorio Hurtado S, Geneletti D, Krkoška Lorencová E, D’Alonzo V, Krook-Riekkola A, Fokaides PA, Ioannou BI, Foley A, Orru H, Orru K, Wejs A, Flacke J, Church JM, Feliu E, Vasilie S, Nador C, Matosović M, Flamos A, Spyridaki NA, Balzan M V., Fülöp O, Grafakos S, Paspaldzhiev I, Heidrich O. 2019. Dedicated versus mainstreaming approaches in local climate plans in Europe. Renewable and Sustainable Energy Reviews 112. DOI: 10.1016/j.rser.2019.05.014.

Richter B, Goldston D, Crabtree G, Glicksman L, Goldstein D, Greene D, Kammen D, Levine M, Lubell M, Savitz M, Sperling D, Schlachter F, Scofield J, Dawson J. 2008. How America can look within to achieve energy security and reduce global warming. Reviews of Modern Physics 80. DOI: 10.1103/revmodphys.80.s1.

Ruddy BC, Lorenz DL, Mueller DK. 2006. County-level estimates of nutrient inputs to the landsurface of the conterminous United States, 1982-2001. Reston, VA. DOI:

$10.3133 / \operatorname{sir} 20065012$.

Schmidt R, Gravuer K, Bossange A V, Mitchell J, Scow K. 2018. Long-term use of cover crops and no-till shift soil microbial community life strategies in agricultural soil. PLOS ONE 13:e0192953.

Scoones I. 2016. The Politics of Sustainability and Development. Annual Review of Environment and Resources 41:293-319. DOI: 10.1146/annurev-environ-110615-090039.

Seavy NE, Gardali T, Golet GH, Griggs FT, Howell CA, Kelsey R, Small SL, Viers JH, Weigand JF. 2009. Why climate change makes riparian restoration more important than ever: Recommendations for practice and research. Ecological Restoration 27. DOI: 10.3368/er.27.3.330.

Seddon N, Turner B, Berry P, Chausson A, Girardin CAJ. 2019. Grounding nature-based climate solutions in sound biodiversity science. Nature Climate Change 9:84-87. DOI: 10.1038/s41558-019-0405-0.

Simenstad CA, Cordell JR. 2000. Ecological assessment criteria for restoring anadromous salmonid habitat in Pacific Northwest estuaries. Ecological Engineering 15. DOI: 10.1016/S0925-8574(00)00082-3.

Smith JE, Heath LS, Skog KE, Birdsey R a. 2006. Methods for Calculating Forest Ecosystem and Harvested Carbon with Standard Estimates for Forest Types of the United States. USDA Northern Research Station.

Soto-Navarro C, Ravilious C, Arnell A, De Lamo X, Harfoot M, Hill SLL, Wearn OR, Santoro M, Bouvet A, Mermoz S, Le Toan T, Xia J, Liu S, Yuan W, Spawn SA, Gibbs HK, Ferrier S, Harwood T, Alkemade R, Schipper AM, Schmidt-Traub G, Strassburg B, Miles L, Burgess ND, Kapos V. 2020. Mapping co-benefits for carbon storage and biodiversity to inform conservation policy and action. Philosophical Transactions of the Royal Society B: Biological Sciences 375. DOI: 10.1098/rstb.2019.0128.

Spies TA, Long JW, Charnley S, Hessburg PF, Marcot BG, Reeves GH, Lesmeister DB, Reilly MJ, Cerveny LK, Stine PA, Raphael MG. 2019. Twenty-five years of the Northwest Forest Plan: what have we learned? Frontiers in Ecology and the Environment 17:511-520. DOI:

Peer) reviewing PDF | (2021:03:59450:2:0:NEW 25 Jun 2021) 
752

753

754

755

756

757

758

759

760

761

762

763

764

765

766

767

768

769

770

771

772

773

774

775

776

777

778

779

780

781

782

783

784

785

786

787

788

789

790

791

792

793

794

795

796

797

$10.1002 /$ fee. 2101 .

Stöckle C, Higgins S, Kemanian A, Nelson R, Huggins D, Marcos J, Collins H. 2012. Carbon storage and nitrous oxide emissions of cropping systems in eastern Washington: A simulation study. Journal of Soil and Water Conservation 67:365-377. DOI: 10.2489/jswc.67.5.365.

Townsend AR, Howarth RW, Bazzaz FA, Booth MS, Cleveland CC, Collinge SK, Dobson AP, Epstein PR, Holland EA, Keeney DR, Mallin MA, Rogers CA, Wayne P, Wolfe AH. 2003. Human Health Effects of a Changing Global Nitrogen Cycle. Frontiers in Ecology and the Environment 1:240. DOI: 10.2307/3868011.

U.S. Bureau of Land Management. 2018. BLM OR Revegetation Treatment Polygons. Available at https://www.blm.gov/services/geospatial/GISData/oregon (accessed March 19, 2020)

U.S. Census Bureau. 2010. 2010 TIGER/Line Geodatabases. Available at https://www.census.gov/geographies/mapping-files/time-series/geo/tiger-data.2010.html (accessed June 22, 2020)

U.S. Fish \& Wildlife Service. 2015. Willapa Estuary Restoration. Available at https://www.fws.gov/refuge/willapa/conservation/estuary_restoration.html (accessed July 19, 2019)

U.S. Forest Service. 2019. S_USA.SilvReforestation. Available at http://data.fs.usda.gov/geodata/edw/datasets.php (accessed March 18, 2020)

U.S. Geological Survey. 2016. LANDFIRE.US_200BPS. Available at https://www.landfire.gov/bps.php (accessed March 18, 2020)

U.S. Geological Survey. 2018. Burned Area Boundaries Dataset 1984 - 2017. Available at https://mtbs.gov/direct-download (accessed November 15, 2019)

United States v. Washington. 1974. Boldt Decision. 384 F. Supp. 312.

USDA NASS. 2019a. USDA NASS 2017 Census of Agriculture - County Data. Washington D.C.

USDA NASS. 2019b. USDA-National Agricultural Statistics Service, Cropland Data Layer (2008 - 2012).

USDA NASS. 2020. County Agriculture Production. Available at https://www.nass.usda.gov/Surveys/Guide_to_NASS_Surveys/County_Agricultural_Product ion/index.php (accessed June 16, 2020)

WA Governor's Office. 2019. Inslee announces bold climate legislation as part of supplemental budget rollout. Available at https://medium.com/wagovernor/inslee-announces-boldclimate-legislation-as-part-of-supplemental-budget-rollout-75a5a8fc65f0 (accessed April 8, 2020)

Washington Department of Natural Resources. 2021. Trust Lands Performance Assessment Project: Charting a Course for the Future, Legistlative Report 2020. Available at https://www.dnr.wa.gov/publications/em_tlpa_lege_report.pdf(accessed March 20, 2021)

Washington State Department of Commerce. 2019. Washington Maritime Blue launches ambitious plan for economic growth, jobs, ocean health. Available at https://www.commerce.wa.gov/news-releases/growing-the-economy/washington-maritimeblue-launches-ambitious-plan-for-economic-growth-jobs-ocean-health/ (accessed March $11,2021)$

Washington State Department of Health. 2018. 2018 Washington State Health Assessment DOH Pub 78945. Available at www.doh.wa.gov/healthassessment (accessed June 12, 2020)

Washington State Legislature. 2020. Amending state greenhouse gas emission limits for conistiency with the most recent assessment of climate change science. Olympia.

Peer] reviewing PDF | (2021:03:59450:2:0:NEW 25 Jun 2021) 
798 Washington State Office of Financial Management. 2019. 2019 Data Book. Available at 799 https://www.ofm.wa.gov/sites/default/files/public/dataresearch/databook/pdf/databook.pdf $800 \quad$ (accessed June 12, 2020)

801 WDNR. 2018. Washington State Timber Harvest Reports, 2003 to 2017. Available at

802 https://www.dnr.wa.gov/TimberHarvestReports (accessed March 16, 2020)

803 WECY. 2019. Washington State Greenhouse Gas Emission Reduction Limits: Report prepared 804 under RCW 70.235.040. Available at

805

806

807

808

809

810

811

812

813

814 https://fortress.wa.gov/ecy/publications/summarypages/1902031.html (accessed March 30, 2020)

WECY. 2021. Washington State Greenhouse Gas Emissions Inventory: 1990-2018. Available at https://apps.ecology.wa.gov/publications/documents/2002020.pdf(accessed February 12, 2021)

Willson MF, Halupka KC. 1995. Anadromous Fish as Keystone Species in Vertebrate Communities. Conservation Biology 9. DOI: 10.1046/j.1523-1739.1995.09030489.x.

WRCO. 2019. PRISM (PRoject Information SysteM) database. Available at https://rco.wa.gov/recreation-and-conservation-office-grants/apply-for-a-grant/prism/

815 


\section{Table $\mathbf{1}$ (on next page)}

Descriptions of each NCS pathway adapted from Graves et al. (Graves et al., 2020). Pathway definitions were adapted from Cameron et al. (Cameron et al., 2017), Griscom et al. (Griscom et al., 2017), and Fargione et al. (Fargione et al., 2018). 


\begin{tabular}{|c|c|c|}
\hline Theme & Natural Climate Solution & Description \\
\hline \multirow{4}{*}{ 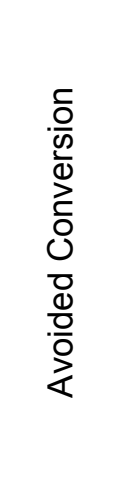 } & $\begin{array}{l}\text { Avoided conversion of forests to } \\
\text { rural development }\end{array}$ & $\begin{array}{l}\text { Emissions avoided by limiting anthropogenic conversion } \\
\text { of forests to low-density and agricultural development. }\end{array}$ \\
\hline & $\begin{array}{l}\text { Avoided conversion of forests to } \\
\text { urban development }\end{array}$ & $\begin{array}{l}\text { Emissions avoided by limiting anthropogenic conversion } \\
\text { of forests to high-density, urban development. }\end{array}$ \\
\hline & $\begin{array}{l}\text { Avoided conversion of } \\
\text { sagebrush-steppe to invasive } \\
\text { annual grasses }\end{array}$ & $\begin{array}{l}\text { Emissions avoided by limiting the conversion, post-fire, of } \\
\text { sagebrush-steppe to invasive annual grasses; assumes } \\
\text { active management of sagebrush-steppe recovery. }\end{array}$ \\
\hline & $\begin{array}{l}\text { Avoided conversion of } \\
\text { grasslands to tilled cropland }\end{array}$ & $\begin{array}{l}\text { Emissions avoided by limiting the anthropogenic } \\
\text { conversion (e.g., tilling) of existing grassland to intensive } \\
\text { agriculture. }\end{array}$ \\
\hline \multirow{4}{*}{ 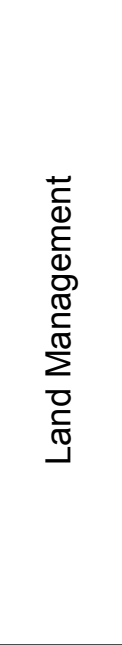 } & $\begin{array}{l}\text { Extended timber harvest } \\
\text { rotations }\end{array}$ & $\begin{array}{l}\text { Avoided emissions and increased sequestration } \\
\text { associated with deferring harvest on a portion of } \\
\text { Washington's forest. We consider timber harvest across } \\
\text { all forest ownerships in Washington but limit deferred } \\
\text { harvest to counties with lower risk of wildfire. }\end{array}$ \\
\hline & Use of cover crops & $\begin{array}{l}\text { Increased carbon sequestration due to use of cover } \\
\text { crops, either to replace fallow periods between main } \\
\text { crops or as inter-row cover in specialty crops such as } \\
\text { orchards, berries, and hops. }\end{array}$ \\
\hline & No-till agriculture & $\begin{array}{l}\text { Increased carbon sequestration due to the use of no-till } \\
\text { agriculture on tilled cropland. }\end{array}$ \\
\hline & Nutrient management & $\begin{array}{l}\text { Avoided emissions from improving } \mathrm{N} \text { fertilizer } \\
\text { management on croplands, through reducing whole-field } \\
\text { application or through variable rate application. }\end{array}$ \\
\hline \multirow{3}{*}{ 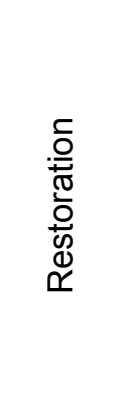 } & $\begin{array}{l}\text { Replanting after wildfire on } \\
\text { federal land }\end{array}$ & $\begin{array}{l}\text { Increased carbon sequestration from increased post- } \\
\text { wildfire reforestation on managed federal lands (e.g., } \\
\text { wilderness areas are not included). This NCS assumes } \\
\text { no salvage harvest or site-prep before replanting. }\end{array}$ \\
\hline & Riparian forest restoration & $\begin{array}{l}\text { Increased carbon sequestration through active replanting } \\
\text { of forest along non-forested riparian areas. }\end{array}$ \\
\hline & Tidal wetland restoration & $\begin{array}{l}\text { Increased carbon sequestration due to restoring tidal } \\
\text { processes where tidal wetlands were the historical } \\
\text { natural ecosystem. }\end{array}$ \\
\hline
\end{tabular}




\section{Table 2 (on next page)}

Assessed NCS pathways listed in descending order by their respective Ambitious potential CO2e reductions in the final year (ca. 2050) of a 30-year deployment for Washington state.

Reductions are shown here as the median of 1,000 Monte Carlo simulations along with the minimum and maximum ends of confidence intervals ranging from $5^{\text {th }}$ to $95^{\text {th }}$ percentiles. 


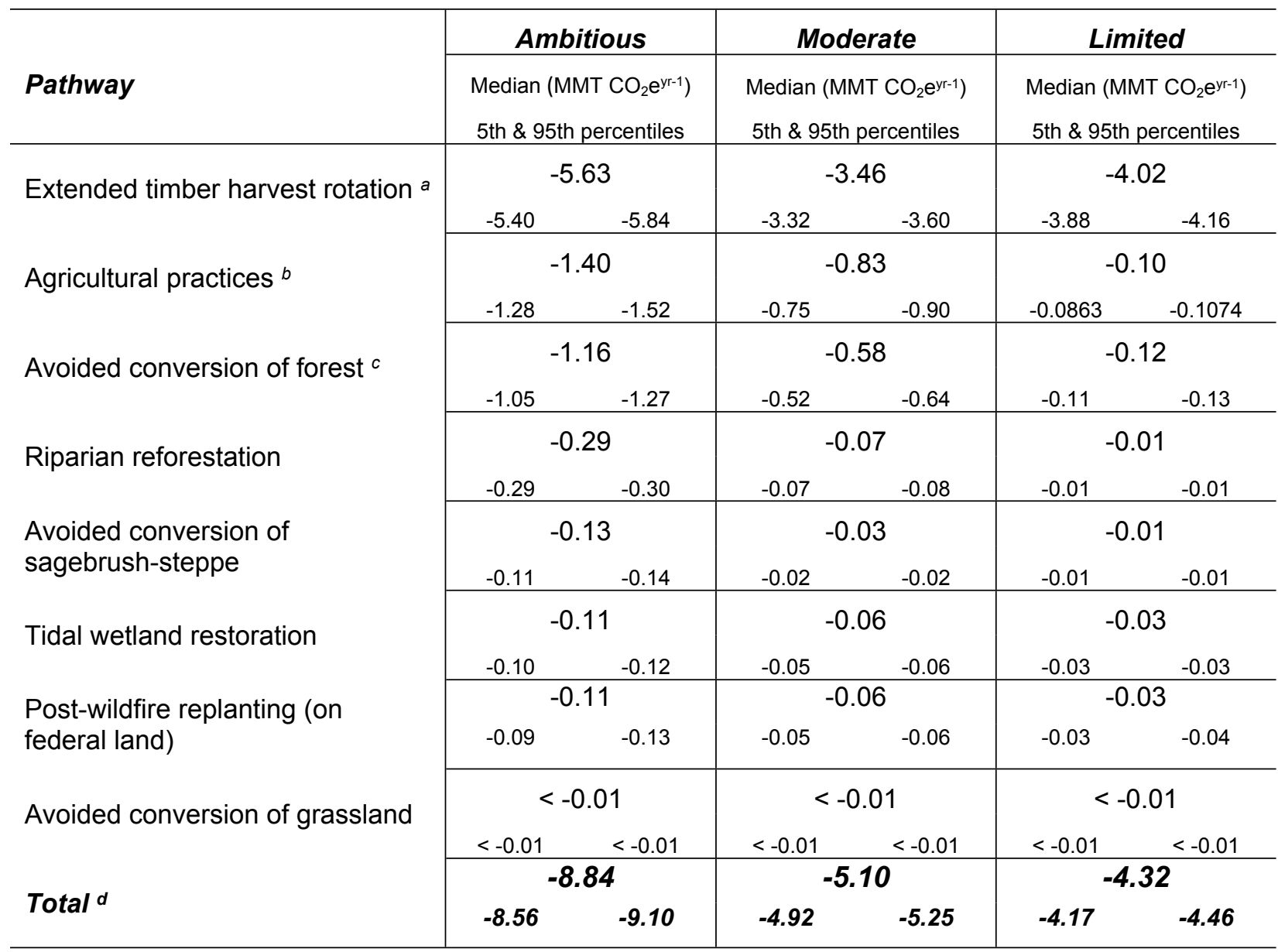

${ }^{a}$ Combination of five activities: harvests on Private, State, Federal, and Other land owner types, and additional sequestration occurring where even-aged management would otherwise likely take place on Private timberlands.

${ }^{b}$ Combination of three activities: cover crops, no-till, and nutrient management on croplands.

${ }^{c}$ Combination of two activities: avoided conversion from forest-to-rural and forest-to-urban development.

${ }^{d}$ Median and confidence intervals of all pathways combined (called Total here) were calculated from all pathways simultaneously and not by summing the median and confidence interval results of each pathway listed in this table. 


\section{Figure 1}

Prominence of the Extended Timber Harvest Rotations pathway among all NCS pathways in the state of Washington.

(A) Total potential reductions from all pathways combined under the Ambitious scenario in 2050, shown with six equal classes in the displayed value range (minimum to maximum).

Total potential reductions under the Ambitious scenario in 2050 from all pathways except

Extended Timber Harvest Rotations, shown with the same six classes as (A) though the actual range is smaller. Range minimum and maximum are the lowest and highest aggregated potential reductions of all Washington counties.

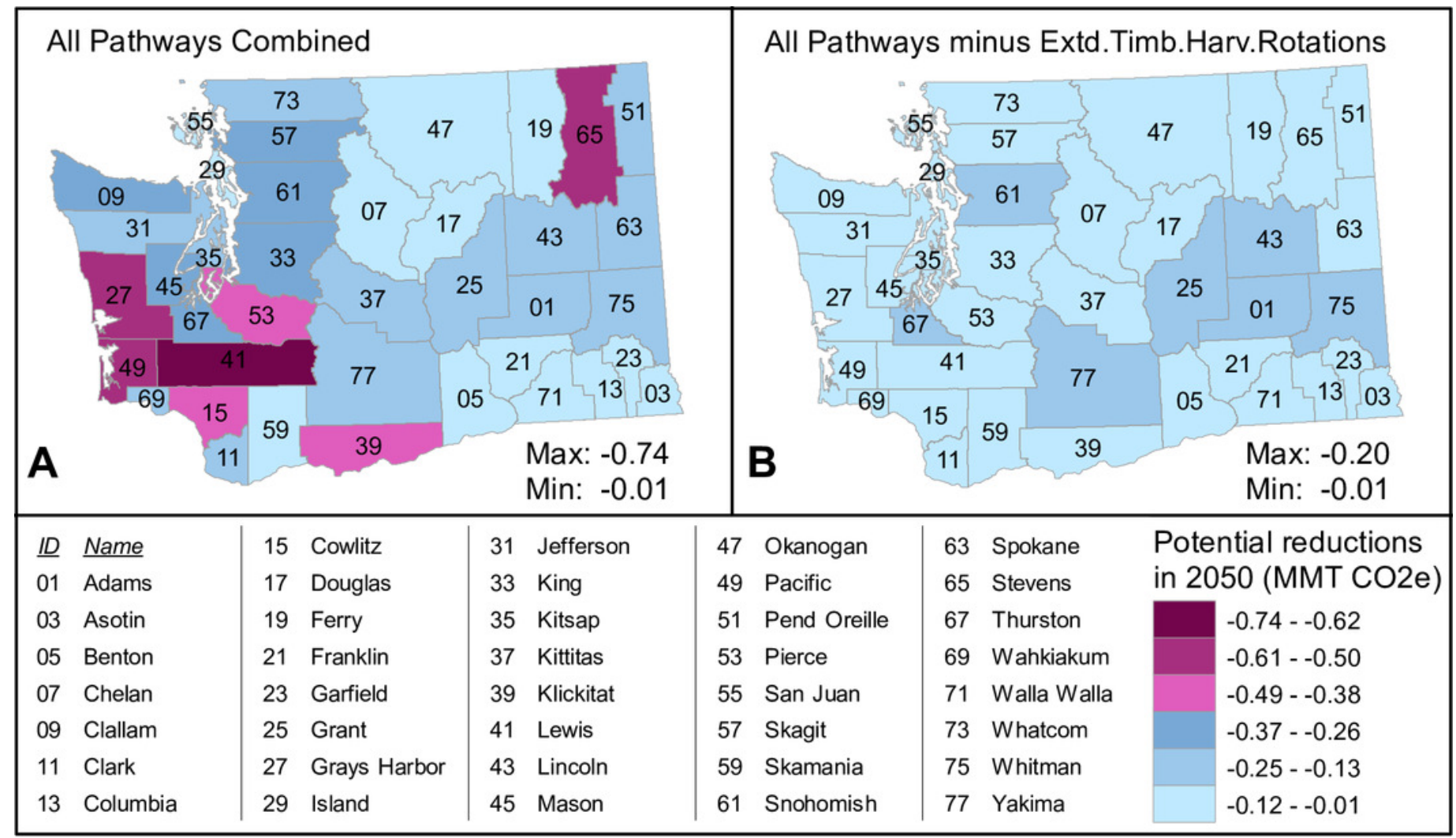




\section{Figure 2}

Potential emissions reductions per county by each pathway in 2050 , arranged by theme (Management, Avoided Conversion, Restoration).

Each map shows six equal classes in a given pathway's stated range (minimum and maximum) of $\mathrm{MMTCO}_{2} \mathrm{e} \mathrm{yr}^{-1}$ in 2050, and therefore ranges differ from map to map. County ID numbers match the county names in the included table. For example, Lewis County (ID 41) has the highest potential reductions of the Extended Timber Harvest Rotations pathway with a value of $-0.6495 \mathrm{MMTCO}_{2} \mathrm{e}$, but Whitman County (ID 75) reductions are near zero.

Conversely, reductions with Cropland Agriculture are near zero in Lewis County and highest in Whitman County with $-0.1980 \mathrm{MMTCO}_{2} \mathrm{e}$, though that highest reduction is much less than Lewis County's Extended Timber Harvest Rotations. 
Figure 3

Map revealing spatial clusters where the highest-potential counties of the three highestpotential pathways provide approximately half of each of those pathway's emissions reductions in 2050.

These NCS clusters are largely driven by major industry sectors within the region.

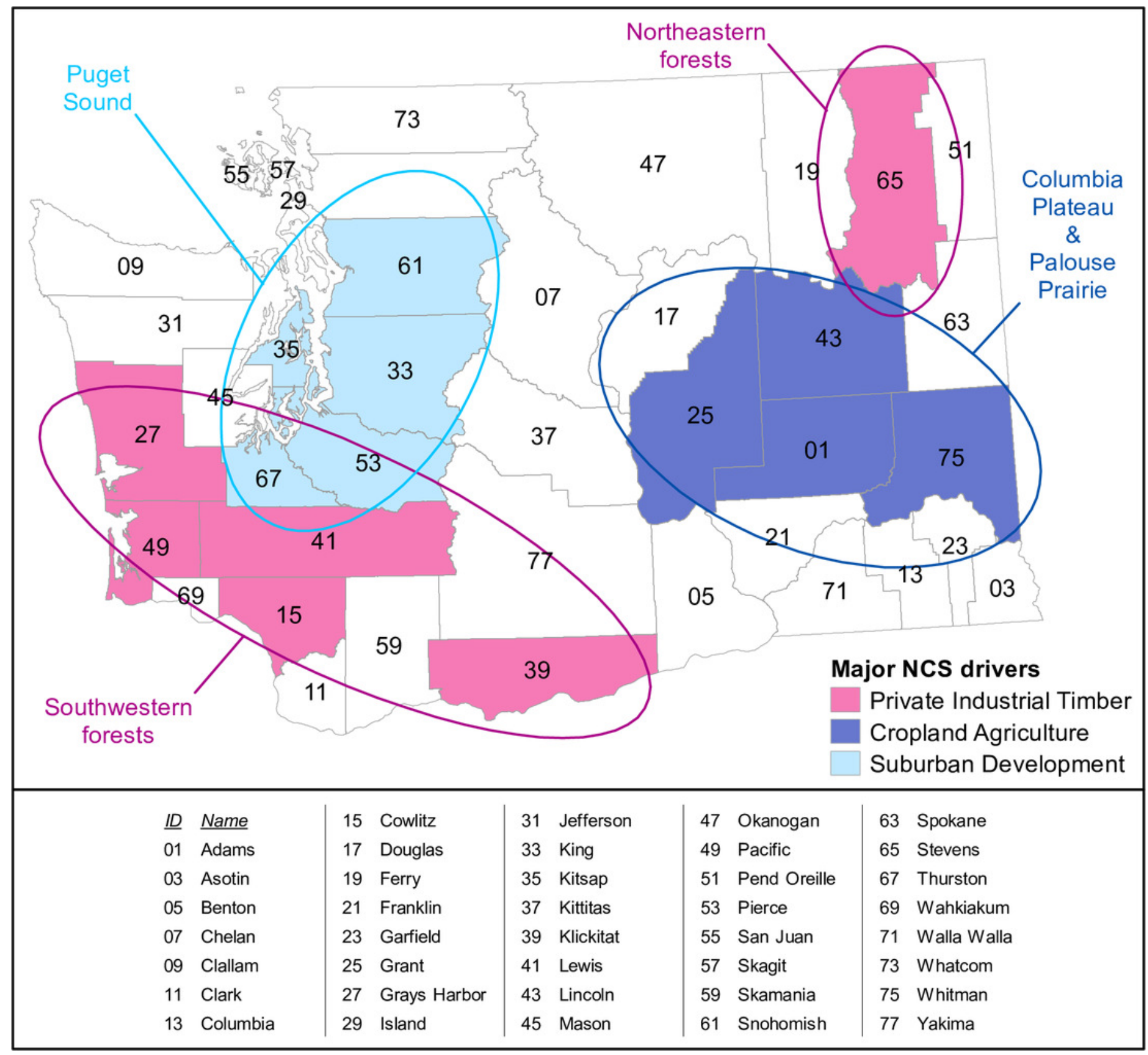

